\title{
AKTSAR
}

ISSN 2622-5255 (online)

Volume 2 Nomor 2, Desember 2019, Halaman 215-232

ISSN 2622-2345 (cetak)

\section{Analisis Pengaruh Pembiayaan Murabahah, Tingkat Bagi Hasil, dan Suku Bunga Acuan BI Terhadap Volume Pembiayaan Mudharabah Perbankan Syariah di Indonesia (Periode 2016-2018)}

\author{
Emy Widyastuti \\ Institut Agama Islam Negeri Salatiga \\ emywidyastuti@iainsalatiga.ac.id
}

\begin{abstract}
The purpose of this study is to analyze the influence of murabahah financing, profitsharing rate and BI rate on the volume of Islamic banking mudharabah financing in Indonesia during the period of 2016-2018. The sample used in this study is all Islamic Commercial Banks in Indonesia in 2016-2018. The data analysis method used in this study is multiple linear regression to find the effect of each variable on the volume of mudharabah financing of Islamic banking in Indonesia. The results showed that simultaneously murabahah financing variables, profit-sharing rates, and BI reference interest rates influenced mudharabah financing. While partially murabahah financing variable and BI reference interest rate have a significant negative effect on mudharabah financing, while the interest rate variable has a significant positive effect on mudharabah financing. The limitation of this study is that it uses a few variables so that it has not been able to show the full variables that affect mudharabah financing volume.
\end{abstract}

Keywords: Murabahah financing; Profit-sharing rate; BI rate; Mudharabah financing; Islamic Commercial Bank 


\begin{abstract}
ABSTRAK
Tujuan dari penelitian ini adalah untuk menganalisis pengaruh pembiayaan murabahah, tingkat bagi hasil dan suku bunga acuan BI pada volume pembiayaan mudharabah Bank Syariah di Indonesia selama periode 2016-2018. Sampel yang digunakan dalam penelitian ini adalah semua Bank Umum Syariah di Indonesia pada 2016-2018. Metode analisis data yang digunakan dalam penelitian ini adalah regresi linier berganda untuk menemukan pengaruh masing-masing variabel terhadap volume pembiayaan mudharabah perbankan syariah di Indonesia. Hasil penelitian menunjukkan bahwa secara simultan variabel pembiayaan murabahah, tingkat bagi hasil, dan suku bunga acuan BI mempengaruhi pembiayaan mudharabah. Sedangkan variabel pembiayaan murabahah dan suku bunga acuan BI secara parsial berpengaruh negatif signifikan terhadap pembiayaan mudharabah, dan variabel suku bunga berpengaruh positif signifikan terhadap pembiayaan mudharabah. Keterbatasan penelitian ini adalah hanya menggunakan beberapa variabel saja sehingga belum mampu menunjukkan pengaruhnya terhadap volume pembiayaan mudharabah.
\end{abstract}

Kata kunci: Pembiayaan murabahah; Tingkat bagi hasil; Suku bunga acuan BI; Pembiayaan mudharabah; Bank umum syariah

\title{
PENDAHULUAN
}

Dalam sistem perekonomian sebuah negara, perbankan memiliki peran besar dalam pertumbuhan dan perkembangan ekonomi. Stabilitas perbankan yang sehat dan kuat akan menciptakan ketahanan ekonomi nasional. Perbankan memiliki fungsi sebagai lembaga intermediasi atau perantara dalam perekonomian nasional. Sebagai sebuah lembaga intermediasi, bank berfungsi menghimpun dana dari masyarakat yang kelebihan dana dan menyalurkannya kepada masyarakat yang kekurangan dana.

Indonesia merupakan negara yang menganut dual banking system. Dalam sistem ini, ada dua bank yang beroperasi secara berdampingan yaitu bank konvensional dan bank syariah. Bank konvensional beroperasi dengan sistem bunga, sedangkan bank syariah beroperasi dengan sistem bagi hasil. Perhitungan bunga yang berlaku di bank konvensional berasal dari tingkat suku bunga acuan yang ditetapkan oleh Bank Indonesia sebagai Bank Sentral. Sedangkan perhitungan bagi hasil yang ada di bank syariah berasal dari besar kecilnya keuntungan atau kerugian yang dialami oleh pengelola dana (mudharib) dalam akad pembiayaan mudharabah.

Bank syariah merupakan bank yang beroperasi sesuai dengan prinsip-prinsip hukum syariah. Dalam aktivitas penyaluran dana kepada masyarakat atau biasa disebut dengan pembiayaan, bank syariah dapat menggunakan berbagai akad yang 
ada dalam bank syariah yang sesuai dengan hukum syariah. Akad pembiayaan yang digunakan dapat berupa akad murabahah (jual beli), mudharabah (bagi hasil), musyarakah, salam, istishna', ijarah dan qardh.

Berdirinya perbankan syariah bertujuan untuk memperkenalkan suatu sistem untuk menggantikan mekanisme bunga dalam transaksi perbankan, yaitu transaksi berbasis profit and loss sharing atau dikenal di Indonesia dengan sistem bagi hasil (Imama, 2014). Secara teoritis, akad mudharabah dengan sistem bagi hasilnya merupakan identitas dari bank syariah karena bagi hasil merupakan pembeda dengan bunga pada bank konvensional. Dengan penggunaan akad mudharabah diharapkan akan terwujud keadilan untuk pihak-pihak yang terlibat yaitu pemilik dana (shahibul maal) dan pengelola dana (mudharib) dari kegiatan usaha yang dilakukan sesuai dengan maqasid syariah.

Akad mudharabah diharapkan dapat meningkatkan sektor ekonomi riil yang akan meningkatkan kesejahteraan masyarakat dan perekonomian nasional. Idealnya, karena bagi hasil merupakan identitas bank syariah, akad mudharabah harus lebih banyak digunakan oleh bank-bank syariah dalam menyalurkan dananya. Namun pada kenyataannya, di beberapa negara termasuk Indonesia justru pembiayaan murabahah (jual-beli) yang lebih mendominasi pembiayaan syariah daripada pembiayaan mudharabah (bagi hasil). Data dari Otoritas Jasa Keuangan menunjukkan komposisi pembiayaan perbankan syariah yang ada di Indonesia pada tahun 2016 sampai dengan tahun 2018 menunjukkan bahwa jumlah pembiayaan murabahah mendominasi pembiayaan yang paling banyak disalurkan oleh bank syariah.

Tabel 1. Komposisi Pembiayaan Syariah

\begin{tabular}{clccc}
\hline No. & Jenis Pembiayaan & $\mathbf{2 0 1 6}$ & $\mathbf{2 0 1 7}$ & (Dalam Milyar) \\
\hline 1. & Mudharabah & $\mathbf{7 , 5 7 7}$ & $\mathbf{6 , 5 8 4}$ & 5,477 \\
\hline 2. & Musyarakah & 50,546 & 57,324 & 65,100 \\
\hline 3. & Murabahah & 105,112 & 110,079 & 115,253 \\
\hline 4. & Qardh & 3,883 & 5,474 & 6,839 \\
\hline 5. & Istishna' & 25 & 18 & 15 \\
\hline 6. & Ijarah & 1,636 & 2,609 & 3,071 \\
\hline 7. & Salam & - & - & - \\
\hline Sumber: OJK (diolah) & & &
\end{tabular}

Pembiayaan murabahah mengalami peningkatan dari tahun 2016 sebesar 105,112 miliar rupiah menjadi sebesar 115,253 miliar rupiah pada tahun 2018. Sedangkan pembiayaan mudharabah mengalami penurunan yaitu pada tahun 2016 sebesar 7,577 Miliar rupiah menjadi 5,477 miliar rupiah pada tahun 2018. Trend ini menunjukkan bahwa pembiayaan murabahah lebih banyak disalurkan dalam beberapa tahun terakhir ini dibandingkan dengan pembiayaan mudharabah.

Transaksi Murabahah dalam Lembaga Keuangan Syariah khususnya perbankan syariah menempati porsi yang paling besar, bahkan pada Bank Pembiayaan Rakyat Syariah hampir seluruh transaksi penyaluran dananya mempergunakan prinsip jual beli Murabahah. Salah satu penyebabnya adalah paradigma para pelaksana Bank 
Syariah yang menyamakan atau membandingkan dengan Bank Konvensional. Murabahah dianalogkan dengan Kredit Kendaraan Bermotor (KKB) dan Kredit Kepemilikan Rumah (KPR) yang dilaksanakan oleh Bank Konvensional, dimana secara konsep jelas keduanya memiliki perbedaan yang mendasar (Wiroso, 2011).

Pembiayaan murabahah menjadi pembiayaan yang diminati oleh bank-bank syariah dan juga masyarakat. Hal ini bukan tanpa alasan, pembiayaan murabahah (jual beli) diperhitungkan sebagai pembiayaan yang memiliki resiko yang lebih kecil daripada pembiayaan mudharabah. Selain itu, pembiayaan murabahah memiliki kejelasan dalam tingkat pengembalian dana yang telah disalurkan beserta dengan margin atau keuntungan yang diambil oleh bank syariah. Alasan lainnya adalah pembiayaan murabahah dapat digunakan untuk pembiayaan barang-barang konsumtif. Berbeda dengan pembiayaan mudharabah (bagi hasil) dimana modal yang akan digunakan dalam kegiatan usaha $100 \%$ berasal dari pemilik dana (shohibul maal) dalam hal ini adalah bank syariah sedangkan pengelola dana hanya sebagai pelaksana yang akan menjalankan dan mengelola usaha namun tidak menanggung kerugian jika usaha yang dijalankan mengalami penurunan usaha atau kebangkrutan asalkan tidak disebabkan oleh faktor kelalaian. Penerapan prinsip bagi hasil tersebut tidaklah mudah karena jenis akad mudharabah terdapat banyak resiko dan membutuhkan biaya operasional yang lebih (Qomar, 2018).

Kemudahan yang ditawarkan oleh pembiayaan murabahah melalui kepastian keuntungan dan resiko yang kecil ini mengakibatkan banyak manajeman bank-bank syariah yang ada di Indonesia lebih memilih pembiayaan murabahah daripada mudharabah atau jenis akad pembiayaan lainnya untuk penyaluran dana kepada masyarakat. Dominasi pembiayaan murabahah ini tentunya akan mempengaruhi besarnya volume pembiayaan mudharabah dalam sebuah bank.

Selain itu, bank-bank syariah juga harus menghadapi tantangan lain yaitu bagi hasil. Keputusan manajemen bank syariah untuk menunjukkan identitasnya dengan penyaluran dana melalui pembiayaan mudharabah juga terkendala dengan nisbah bagi hasil yang akan ditawarkan kepada masyarakat. Pada sisi internal, bank syariah juga sebagai salah satu lembaga keuangan yang bertujuan untuk mencari keuntungan akan berusaha mendapatkan keuntungan semaksimal mungkin. Namun pada sisi eksternal, beberapa masyarakat juga akan mempertimbangkan bagi hasil yang akan diperoleh dari bank syariah. Jika bagi hasil yang ditawarkan kepada masyarakat besar, hal ini akan mampu menarik minat masyarakat. Namun konsekuensi yang harus dihadapi oleh bank syariah adalah pendapatan bagi hasil untuk bank syariah menjadi kecil. Kebijakan tentang besar kecilnya tingkat bagi hasil yang akan ditawarkan bank syariah kepada masyarakat ini akan berpengaruh pada volume pembiayaan mudharabah yang akan disalurkan kepada masyarakat.

Bagi hasil yang akan diberikan oleh bank syariah tidak ditentukan oleh suku bunga acuan yang ditetapkan oleh Bank Indonesia. Berbeda dengan Bank Konvensional yang memberikan bunga berdasarkan suku bunga acuan dari Bank Indonesia, bank syariah beroperasi dengan prinsip bagi hasil sesuai syariah. Pada kenyataannya, perubahan tingkat suku bunga BI akan mempengaruhi rate pembiayaan di bank syariah dalam hal ini adalah pembiayaan mudharabah. Hal ini disebabkan kenaikan tingkat suku bunga BI akan berdampak langsung terhadap perbankan syariah. Tingkat suku bunga yang fluktuatif akan mempengaruhi jumlah 
pembiayaan di bank syariah. Masyarakat yang lebih tergiur untuk mendapatkan bunga yang tinggi akan menempatkan dananya di bank konvensional (displaced commercial risk). Hal ini akan menghambat kegiatan penghimpunan dana bank syariah yang nantinya akan disalurkan ke berbagai jenis pembiayaan dalam hal ini adalah pembiayaan mudharabah.

Penelitian ini bertujuan untuk menganalisis pengaruh pembiayaan murabahah, tingkat bagi hasil dan tingkat suku bunga acuan Bank Indonesia terhadap pembiayaan mudharabah perbankan syariah yang ada di Indonesia periode 2016-2018. Banyak penelitian yang telah membahas tentang faktor-faktor yang mempengaruhi pembiayaan mudharabah yang ada di bank syariah. Di antaranya adalah penelitian yang dilakukan oleh Pratin (2005), Widiyanto (2015), Ali (2016), Yaya (2016), Naufal (2017).

Pratin (2005) melakukan penelitian tentang analisis hubungan simpanan, modal sendiri, NPL, prosentase bagi hasil dan mark up keuntungan terhadap pembiayaan pada perbankan syariah studi kasus pada Bank Muamalat Indonesia. Hasil penelitiannya menunjukkan bahwa hanya variabel margin yang mempunyai pengaruh negatif terhadap pembiayaan pada perbankan syariah (Bank Muamalat Indonesia).

Penelitian yang dilakukan oleh Widiyanto (2015) tentang analisis pengaruh tingkat suku bunga BI terhadap pembiayaan mudharabah menunjukkan hasil bahwa ada pengaruh antara BI rate dengan tingkat dan proporsi bagi hasil pembiayaan mudharabah. Selanjutnya penelitian yang dilakukan oleh Ali (2016) tentang analisis pengaruh dana pihak ketiga (DPK), non performing financing dan tingkat suku bunga kredit terhadap pembiayaan berbasis mudharabah (bagi hasil) pada perbankan syariah Indonesia menunjukkan hasil bahwa hanya non performing financing tidak mempunyai pengaruh terhadap pembiayaan bagi mudharabah (bagi hasil) pada perbankan syariah.

Penelitian yang dilakukan oleh Yaya (2016) mengenai faktor-faktor yang mempengaruhi volume dan porsi pembiayaan berbasis bagi hasil pada perbankan syariah di Indonesia menunjukkan bahwa CAR berpengaruh terhadap volume dan porsi pembiayaan bagi hasil, sedangkan DPK hanya berpengaruh terhadap volume pembiayaan bagi hasil. Selanjutnya penelitian yang dilakukan oleh Naufal et al., (2017) tentang pengaruh DPK, rasio keuangan bank, inflasi dan BI rate terhadap volume pembiayaan pada bank umum syariah menunjukkan hasil bahwa inflasi dan BI rate tidak berpengaruh terhadap volume pembiayaan.

Penelitian ini bertujuan untuk menganalisis faktor lain yang belum digunakan sebagai variabel independen, yaitu pembiayaan murabahah. Hal ini dimaksudkan untuk memberikan gambaran yang jelas bagaimanakah sebenarnya pengaruh secara langsung pembiayaan murabahah terhadap pembiayaan mudharabah dengan melihat kenyaataan bahwa pembiayaan murabahah mendominasi pembiayaan di bank syariah.

\section{TINJAUAN LITERATUR}

\section{Bank Syariah}

Bank adalah lembaga yang melaksanakan tiga fungsi utama yaitu menerima simpanan uang, meminjamkan uang dan mengirimkan jasa pengiriman uang (Karim, 
2014: 18). Bank Islam adalah bank yang beroperasi sesuai dengan prinsip syariah Islam atau bank yang tata cara beroperasinya mengacu kepada ketentuan Al-Qur'an dan Hadist (Antonio, 2000).

Bank syariah merupakan bank yang dalam aktivitasnya, baik perhimpunan dana maupun dalam rangka penyaluran dananya memberikan dan mengenakan imbalan atas dasar prinsip utama operasional bank syariah adalah prinsip syariah, yaitu hokum Islam yang bersumber pada Al-Qur'an dan Al-Hadist. Bank syariah memiliki kegiatan usaha yang lebih luas dari bank konvensional. Bank syariah tidak membedakan bergerak di bidang sekor keuangan atau sektor riil sebagaimana bank konvensional.

Menurut Wiroso (2011: 6), salah satu fungsi bank syariah yang sangat penting adalah manager investasi. Bank syariah merupakan manager investasi dari pemilik dana (shohibul maal) dari dana yang dihimpun dengan prinsip mudharabah, karena besar kecilnya imbalan bagi hasil yang diterima oleh pemilik dana sangat tergantung pada hasil usaha yang diperoleh (dihasilkan) oleh bank syariah dalam mengelola dana. Bank syariah dapat menghimpun dana yang besar namun harus dilakukan dengan efektif dan penuh dengan kehati-hatian karena akan mempengaruhi hasil usaha yang diikuti dengan aliran kas masuk (cash basis). Dana yang dihimpun oleh bank syariah, hendaknya ditanamkan pada sektor yang produktif dan tidak melanggar syariah, karena sesuai konsep syariah apa yang dilakukan oleh bank syariah dalam penyaluran dana akan membawa dampak atau resiko kepada pemilik dana dari dana yang dihimpun.

Selain itu, ada satu fungsi penting bank syariah yaitu fungsi sosial. Dalam konsep perbankan syariah mengharuskan bank dan Lembaga Keuangan Syariah memberikan pelayan sosial apakah melalui dana Qardh (pinjaman kebajikan) atau zakat dan dana sumbangan sesuai dengan prinsip-prinsip Islam. Selain itu, konsep perbankan Islam juga mengharuskan bank-Lembaga Keuangan Syariah untuk memainkan peran penting di dalam pengembangan sumber daya manusianya dan memberikan kontribusi bagi perlindungan dan pengembangan lingkungan.

\section{Pembiayaan}

Pembiayaan adalah pendanaan yang dikeluarkan oleh suatu pihak kepada pihak lain untuk mendukung investasi yang telah direncanakan. Pembiayaan juga memiliki beberapa tujuan yaitu mencapai tingkat profitabilitas yang cukup dan tingkat resiko yang rendah dan mempertahankan kepercayaan masyarakat dengan menjaga agar posisi likuiditas tetap aman (Muhamad, 2005).

Menurut UU No 10 tahun 1998 tentang perbankan pasal 1 menjelaskan bahwa pembiayaan berdasarkan prinsip syariah adalah penyediaan uang atau tagihan yang dipersamakan dengan itu berdasarkan persetujuan atau kesepakatan antara bank dengan pihak lain yang mewajibkan pihak yang dibiayai untuk mengembalikan uang atau tagihan tersebut setelah jangka waktu tertentu dengan imbalan atau bagi hasil.

Menurut Wiroso (2011) macam-macam pembiayaan dalam perbankan syariah terdiri dari Murabahah, Salam, Istishna', Mudharabah, Musyarakah. Murabahah adalah menjual suatu barang dengan menegaskan harga belinya kepada pembeli dan pembeli membayarnya dengan harga yang lebih tinggi sebagai laba. Mudharabah, usaha yang beresiko (risk business) adalah akad kerjasama usaha antara pihak pemilik 
dana (shahib al-mal) dengan pihak pengelola dana (mudharib) dimana keuntungan dibagi sesuai nisbah yang disepakati, sedangkan kerugian ditanggung pemilik dana (modal).

Dalam PSAK 102 Murabahah adalah menjual barang dengan harga jual sebesar harga perolehan ditambah keuntungan yang disepakati dan penjual harus mengungkapkan harga perolehan barang tersebut kepada pembeli. Mudharabah didefinisikan sebagai akad kerja sama antara bank selaku pemilik dana (Shohib alMaal) dengan nasabah selaku mudharib yang mempunyai keahlian atau ketrampilan untuk mengelola suatu usaha yang produktif dan halal. Hasil keuntungan dari penggunaan dana tersebut dibagi bersama berdasarkan nisbah yang disepakati (Muhamad, 2016).

Sedangkan Mudharabah menurut PSAK 105 adalah akad kerjasama usaha antara dua pihak dimana pihak pertama (pemilik dana) menyediakan seluruh dana, sedangkan pihak kedua (pengelola dana) bertindak selaku pengelola dan keuntungan usaha dibagi di antara mereka sesuai kesepakatan sedangkan kerugian finansial hanya ditanggung oleh pemilik dana.

\section{Bagi Hasil dan Suku Bunga BI}

Dalam pembiayaan terdapat unsur bagi hasil. Bagi hasil adalah suatu system pengolahan dana dalam perekonomian Islam yakni pembagian hasil usaha antara pemilik modal (shahibul maal) dan pengelola (mudharib) (Antonio, 2001: 90). Salah satu keunikan Bank Syariah adalah dengan prinsip bagi hasilnya, khususnya mudharabah. Mudharabah merupakan transaksi yang harus dilaksanakan atas dasar kepercayaaan. Kepercayaan harus didasari dengan penerapan akidah, akhlaq dan moral sesuai dengan ketentuan-ketentuan syariah.

Bank syariah menerapkan nisbah bagi hasil terhadap produk-produk pembiayaan yang berbasis NUC (Natural Uncertainty Contract) yakni akad bisnis yang tidak memberikan kepastian pendapatan baik dari jumlah maupun waktu (Karim, 2004). Penetapan nisbah bagi hasil pembiayaan ditentukan dengan mempertimbangkan referensi tingkat margin keuntungan dan perkiraan tingkat keuntungan bisnis/proyek yang dibiayai (Pratin, 2005).

Tujuan dalam mudharabah adalah memberikan imbalan kepada pemilik dana dari hasil usaha yang diperoleh oleh pengelola dana yang besarnya disepakati diawal, sehingga hasil yang diperoleh dari pemilik dana sangat tergantung pada pengelola dana, pemilik dana tidak diperkenankan meminta imbalan pasti dalam bentuk nominal di muka.

Perhitungan pembagian hasil usaha selalu dilakukan oleh mudharib, karena dalam mudharabah pekerjaan merupakan hak exclusif dari mudharib, pemilik dana tidak diperkenankan terlibat dalam manajemen usaha, pemilik dana hanya memiliki hak untuk melakukan pengawasan. Oleh karena itu yang mengetahui hasil dari usaha adalah pengelola dana begitu juga dengan pembagian hasilnya dilakukan oleh pengelola dana (Wiroso, 2011).

Lain dengan bank syariah yang memberikan imbal hasil berdasarkan bagi hasil, bank konvensional memberikan imbal hasil berdasarkan suku bunga yang ditetapkan. Suku bunga yang ditetapkan tentu saja mengacu pada BI rate. BI rate adalah suku bunga dengan tenor satu bulan yang diumumkan Bank Indonesia secara 
periodik untuk jangka waktu tertentu yang berfungsi sebagai sinyal (stance) kebijakan moneter (Dahlan Siamat, 2005:139). Menurut Rose dan Kolari (1995) jumlah permintaan pembiayaan/pinjaman (loan) oleh masyarakat berhubungan terbalik dengan tingkat suku bunga. Atau dengan kata lain semakin tinggi tingkat suku bunga maka akan sedikit jumlah permintaan pinjaman dan sebaliknya.

Jumlah penawaran pembiayaan oleh bank berhubungan searah dengan tingkat suku bunga atau semakin tinggi tingkat suku bunga maka semakin tinggi pembiayaan yang ditawarkan. Saat ini BI rate digantikan oleh BI 7-days (reverse) Repo Rate. Bank Indonesia melakukan penguatan kerangka operasi moneter dengan mengimplementasikan suku bunga acuan atau suku bunga kebijakan baru yaitu BI 7days (reverse) Repo Rate yang berlaku efektif sejak 19 Agustus 2016 menggantikan BI Rate (www.bi.go.id).

\section{Pengembangan Hipotesis}

\section{Pembiayaan Murabahah terhadap volume pembiayaan mudharabah}

Prinsip bagi hasil dalam akad mudharabah adalah kemitraan dan kebersamaan (sharing) antara investor (shohibul maal) dan pelaku usaha (mudharib), di mana di dalamnya terdapat unsur-unsur kepercayaan (amanah), kejujuran dan kesepakatan (Sa'diyah, 2013). Penerapan prinsip bagi hasil tersebut tidaklah mudah karena jenis akad mudharabah terdapat banyak resiko dan membutuhkan biaya operasional yang lebih. Dalam perkembangan transaksi pembiayaan oleh bank syariah di Indonesia lebih mengandalkan skema pembiayaan Murabahah (jual-beli) dibanding dengan skema pembiayaan Mudharabah (bagi-hasil). Tingginya resiko pada akad mudharabah menjadikan alasan mengapa praktisi perbankan lebih memilih penyaluran pembiayaan kepada masyarakat menggunakan akad murabahah, akad ini dinilai lebih rendah resikonya dan pasti keuntungannya (Qomar, 2018).

Berdasarkan uraian diatas, hipotesis dapat dirumuskan sebagai berikut:

\section{H1 : pembiayaan murabahah berpengaruh signifikan terhadap pembiayaan mudharabah}

\section{Tingkat bagi hasil terhadap volume pembiayaan mudharabah}

Dalam menjalankan kegiatan operasional perusahaan, bank syariah mempunyai fungsi sebagai entitas bisnis yang bersifat non-profit oriented (nirlaba) dan profit oriented (mencari keuntungan). Dalam kegiatan mencari keuntungan bank syariah akan mencari dan memilih jenis pembiayaan yang memberikan pendapatan dan keuntungan besar. Besarnya keuntungan yang diperoleh oleh bank syariah akan mempengaruhi besar kecilnya tingkat bagi hasil yang akan diberikan bank syariah kepada nasabahnya.

Sebagian masyarakat cenderung mengutamakan keuntungan sehingga memilih bank yang mampu memberikan imbal hasil terbaik di antara bank-bank lainnya, baik itu bank syariah maupun bank konvensional. Tingkat bagi hasil yang tinggi membuat lebih banyak nasabah memilih deposito mudharabah dibandingkan deposito konvensional. Sebaliknya, jika suku bunga tinggi, diperkirakan nasabah cenderung mendepositokan dananya pada deposito bank konvensional (Ruhlizar, 2016). 
Berdasarkan uraian diatas, hipotesis dapat dirumuskan sebagai berikut:

H2 : Tingkat bagi hasil berpengaruh signifikan terhadap volume pembiayaan mudharabah

\section{Tingkat suku bunga acuan BI terhadap volume pembiayaan mudharabah}

Menurut Widiyanto dan Diyani (2015) pembiayaan mudharabah tidak terpengaruh oleh tingkat suku bunga atau BI rate karena pembiayaan mudharabah secara umum adalah perjanjian finansial antara pemilik modal yang memberikan sejumlah dana yang disepakati dengan pengelola dana dimana pengelola dana jika mendapatkan keuntungan dari penggunaan modal yang diberikan akan dibagi secara bersama-sama sesuai kesepakatan dan jika ada kerugian yang ditimbulkan maka akan ditanggung bersama-sama sesuai dengan kesepakatan bersama awal. Pada prakteknya, jika ada kenaikan dan penurunan BI rate maka akan memperngaruhi tingkat rate pembiayaan perbankan syariah terhadap jasa pembiayaan mudharabah.

Berdasarkan uraian diatas, hipotesis dapat dirumuskan sebagai berikut:

H3: Tingkat suku bunga acuan BI berpengaruh signifikan terhadap volume pembiayaan mudharabah.

\section{METODE}

\section{Metode Penelitian}

Populasi dalam penelitian ini adalah seluruh bank umum syariah yang ada di Indonesia mulai tahun 2016 sampai dengan tahun 2018. Teknik pengambilan sampel dalam penelitian ini adalah purposive sampling dengan kriteria: 1) Bank syariah yang mempunyai status sebagai Bank Umum Syariah, 2) Bank umum syariah yang memiliki dan mempublikasikan laporan keuangan lengkap untuk periode penelitian tahun 2016 sampai dengan tahun 2018. Data yang digunakan dalam penelitian ini adalah data sekunder kuantitatif. data sekunder diperoleh dari laporan keuangan tahunan yang dipublikasikan oleh seluruh bank umum syariah yang ada di Indonesia tahun 2016-2018 dan tercantum di Otoritas Jasa Keuangan.

\section{Definisi Operasional Variabel}

\section{Pembiayaan mudharabah (Y)}

Pembiayaan mudharabah merupakan jenis pembiayaan yang berbasis bagi hasil pada perbankan syariah. Variabel ini diukur dengan agregat nilai pembiayaan mudharabah yang telah disalurkan oleh perbankan syariah kepada masyarakat.

\section{Pembiayaan Murabahah (X1)}

Pembiayaan murabahah merupakan jenis pembiayaan berbasis jual beli barang pada perbankan syariah. Variabel ini diukur dengan agregat nilai nilai pembiayaan murabahah yang disalurkan kepada masyarakat oleh perbankan syariah.

\section{Tingkat Bagi Hasil (X2)}

Tingkat bagi hasil merupakan tingkat imbalan yang diberikan oleh bank syariah atas pembiayaan musyarakah dan mudharabah yang disalurkannya pada waktu 
tertentu yang merupakan hasil perbandingan perkembangan tingkat bagi hasil dengan periode sebelumnya. Tingkat bagi hasil dihitung dengan menggunakan rumus :

Tingkat Bagi Hasil $=\frac{\text { bagi hasil yang diterima nasabah }}{\text { total pembiayaan berbasis bagi hasil }}$

\section{Tingkat Suku Bunga Acuan BI (X3)}

Merupakan suku bunga acuan yang dikeluarkan oleh Bank Indonesia selaku bank sentral dalam kebijakan moneternya. Saat ini suku bunga acuan BI digantikan dengan suku bunga kebijakan baru atau disebut dengan BI 7-days (reverse) repo rate yang berlaku efektif sejak 19 Agustus 2016. BI Rate atau yang sekarang disebut dengan BI 7-days (reverse) repo rate digunakan sebagai suku bunga kebijakan baru karena dapat secara cepat mempengaruhi pasar uang, perbankan, dan sektor riil (www.bi.go.id). Kenaikan dan penurunan suku bunga acuan akan mempengaruhi volume pembiayaan di perbankan syariah termasuk jasa pembiayaan mudharabah. Hal ini dapat terjadi dikarenakan kenaikan suku bunga acuan secara langsung akan memberikan dampak bagi perbankan syariah. Dampak yang dimaksud adalah displaced commercial risk yaitu resiko berpindahnya dana dari perbankan syariah ke perbankan konvensional karena adanya perbedaan rate keuntungan yang didapat ketika ada perubahan tingkat suku bunga BI (Widiyanto dan Diyani, 2015).

\section{Analisis Data}

Analisis data yang digunakan dalam penelitian ini adalah model regresi linier berganda. Model regresi linier berganda ini digunkan untuk mengetahui pengaruh pembiayaan murabahah, tingkat bagi hasil dan tingkat suku bunga acuan terhadap volume pembiayaan mudharabah perbankan syariah. Alat analisis dalam penelitian ini menggunakan SPSS for Windows versi 15. Model persamaan regresi yang digunakan adalah sebagai berikut :

$$
\mathrm{Y}=\mathrm{a}+\mathrm{b} 1 \mathrm{X} 1+\mathrm{b} 2 \mathrm{X} 2+\mathrm{b} 3 \mathrm{X} 3+\mathrm{e}
$$

Dimana :

$$
\begin{aligned}
& \mathrm{Y}=\text { volume pembiayaan mudharabah } \\
& \mathrm{a}=\text { konstanta } \\
& \mathrm{bi}=\text { slope } \\
& \mathrm{X} 1=\text { pembiayaan murabahah } \\
& \mathrm{X} 2=\text { tingkat bagi hasil } \\
& \mathrm{X} 3=\text { tingkat suku bunga acuan } \\
& \mathrm{E}=\text { residual }
\end{aligned}
$$

Uji hipotesis dengan melihat nilai t digunakan untuk mengetahui signifikansi pengaruh variabel independen terhadap variabel dependennya. Jika nilai signifikansi t lebih kecil dari derajat kepercayaan (5\%) maka pengaruh variabel independen terhadap variabel dependen adalah signifikan. Menurut Ghozali (2005) model yang baik dapat dilihat berdasarkan nilai adjusted $\mathrm{R}$ squared, nilai $\mathrm{t}$ dan nilai $\mathrm{F}$ nya. Untuk memenuhi persyaratan BLUE (Best Linier Unbiased Estimation) maka perlu dilakukan 
uji asumsi klasik. Uji asumsi klasik dilakukan sebelum pengujian hipotesis yang terdiri dari uji normalitas, multikolinieritas, heterokedastisitas dan autokorelasi.

Pengujian normalitas dilakukan bertujuan untuk mengetahui data berdistribusi normal atau tidak (Hair dkk., 2006: 208). Uji multikolinieritas dilakukan untuk menguji apakah model regresi ditemukan adanya korelasi antar variable bebas (Gujarati, 2004;342). Metode analisis untuk menguji terjadinya multikolinieritas dapat dilihat dari hasil nilai tolerance value atau variance inflation factor (VIF). Uji autokorelasi bertujuan untuk menguji apakah dalam suatu model regresi linier tidak ada korelasi antara kesalahan pengganngu pada periode $t$ dengan kesalahan pada periode $t-1$ (sebelumnya). Jika terjadi korelasi, maka disebut dengan korelasi (Gujarati, 2004; 442). Penelitian ini menggunakan uji DW. Uji heterokedastisitas bertujuan untuk menguji apakah dalam model regresi terjadi ketidaksamaan variance dari residual satu pengamatan ke pengamatan lainnya. Jika variance dari residual satu pengamatan ke pengamatan lainnya tetap, maka disebut homokedastisitas. Model regresi yang baik adalah yang homokedastisitas dan tidak terjadi heterokedastisitas (Gujarati, 2004;390). Uji heterokedastisitas dalam penelitian ini menggunakan Uji Park. Berdasarkan uji heterokedastisitas dengan menggunakan uji Park di atas, nilai sig lebih besar dari 0,05 sehingga tidak terjadi heterokedastisitas.

\section{HASIL DAN PEMBAHASAN}

\section{Hasil Uji Asumsi Klasik}

Berdasarkan hasil uji normalitas menggunakan Kolmogrov-Smirnov dapat disimpulkan bahwa residual berdistribusi normal yaitu dengan melihat nilai signifikansinya sebesar 0,899 yang lebih besar dari 0,05.

Hasil uji multikolinearitas menunjukkan bahwa masing-masing variabel mempunyai nilai tolerance lebih dari 0,10 dan nilai variance inflation factor (VIF) kurang dari 10. Nilai tolerance pembiayaan murabahah, tingkat bagi hasil, dan tingkat suku bunga adalah 0,126, 0,514 dan 0,146. Sedangkan nilai VIF 7,914, 1,945 dan 6,846. Dengan demikian, dapat disimpulkan bahwa persamaan regresi tidak terdapat problem multikolinearitas.

Hasil uji autokorelasi dengan uji Durbin-Watson menghasilkan nilai sebesar 1,978. Sedangkan dl 1,4064 dan du 1,6708. Menurut kriteria du dan 4-du, maka tidak terjadi autokorelasi dalam penelitian ini.

Berdasarkan uji heteroskedastisitas dengan menggunakan uji Park, nilai signifikansi lebih besar dari 0,05 sehingga tidak terjadi heteroskedastisitas.

\section{Hasil Uji Hipotesis}

\section{Hasil Uji Koefisien Determinasi}

Hasil uji koefisien determinasi diperoleh angka $\mathrm{R}^{2}$ sebesar 0,810 atau 81\%. Hal ini menunjukkan bahwa $81 \%$ variabel dependen pembiayaan mudharabah dapat dijelaskan oleh variabel independen yaitu pembiayaan murabahah, tingkat bagi hasil dan tingkat suku bunga acuan BI sedangkan sisanya sebesar 19\% dijelaskan oleh variabel lain di luar model. Berikut tabel hasil pengujian koefisien determinasi: 
Tabel 2. Hasil Uji Koefisien Determinasi

\begin{tabular}{lllll}
\hline & & & & \multicolumn{2}{l}{ Std. Error of the } \\
Model & $\mathrm{R}$ & R Square & Adjusted R Square & Estimate \\
\hline 1 & $.900^{\mathrm{a}}$ & .810 & .797 & .05766
\end{tabular}

Sumber: data diolah

\section{Hasil Uji Statistik $t$}

Hasil uji statistik $\mathrm{t}$ dapat dilihat pada Tabel 3 dibawah ini. Nilai koefisien pembiayaan murabahah sebesar -1,194 dengan nilai signifikansi sebesar 0,000 yang lebih kecil dari alpha ( $($ ) sebesar 0,05 sehingga dapat disimpulkan bahwa pembiayaan murabahah berpengaruh secara signifikan terhadap volume pembiayaan mudharabah dengan arah hubungan yang negatif. Artinya semakin besar jumlah pembiayaan murabahah di perbankan syariah akan menyebabkan volume pembiayaan mudharabah semakin kecil. Nilai koefisien tingkat bagi hasil sebesar 0,051 dengan nilai signifikansi sebesar 0,008 yang lebih kecil dari alpha (a) sebesar 0,05 sehingga dapat disimpulkan bahwa tingkat bagi hasil berpengaruh secara signifikan terhadap volume pembiayaan mudharabah dengan arah hubungan yang positif. Artinya semakin besar tingkat bagi hasil di perbankan syariah akan menyebabkan volume pembiayaan mudharabah semakin besar. Nilai koefisien tingkat suku bunga acuan BI sebesar - 0,043 dengan nilai signifikansi sebesar 0,016 yang lebih kecil dari alpha (a) sebesar 0,05 sehingga dapat disimpulkan bahwa tingkat suku bunga acuan BI berpengaruh secara signifikan terhadap volume pembiayaan mudharabah dengan arah hubungan yang negatif. Artinya semakin besar tingkat suku bunga acuan BI akan menyebabkan volume pembiayaan mudharabah semakin kecil.

Tabel 3. Hasil Uji Statistik $\mathbf{t}$

\begin{tabular}{|c|c|c|c|c|c|}
\hline \multirow[b]{2}{*}{ Model } & \multicolumn{2}{|c|}{$\begin{array}{l}\text { Unstandardized } \\
\text { Coefficients }\end{array}$} & \multicolumn{2}{|c|}{$\begin{array}{l}\text { Standardized } \\
\text { Coefficients }\end{array}$} & \multirow[b]{2}{*}{ Sig. } \\
\hline & $\mathrm{B}$ & Std. E & Beta & $\mathrm{t}$ & \\
\hline 1 (Constant) & 52.592 & 5.420 & & 9.702 & .000 \\
\hline X1 & -1.194 & .204 & -1.082 & -5.846 & .000 \\
\hline$\overline{\mathrm{X} 2}$ & .051 & .018 & .254 & 2.773 & .008 \\
\hline $\mathrm{X} 3$ & -.043 & .017 & -.429 & -2.494 & .016 \\
\hline
\end{tabular}

Sumber : data diolah

Model persamaan regresi yang terbentuk adalah sebagai berikut :

$\mathrm{Y}=52.592-1.194 \mathrm{X} 1+0.051 \mathrm{X} 2-0.043 \mathrm{X} 3+\mathrm{e}$ 


\section{Hasil Uji Statistik F}

Hasil uji statistik F dapat dilihat pada Tabel 4 dibawah ini.

Tabel 4. Hasil Uji Statistik F (ANOVA)

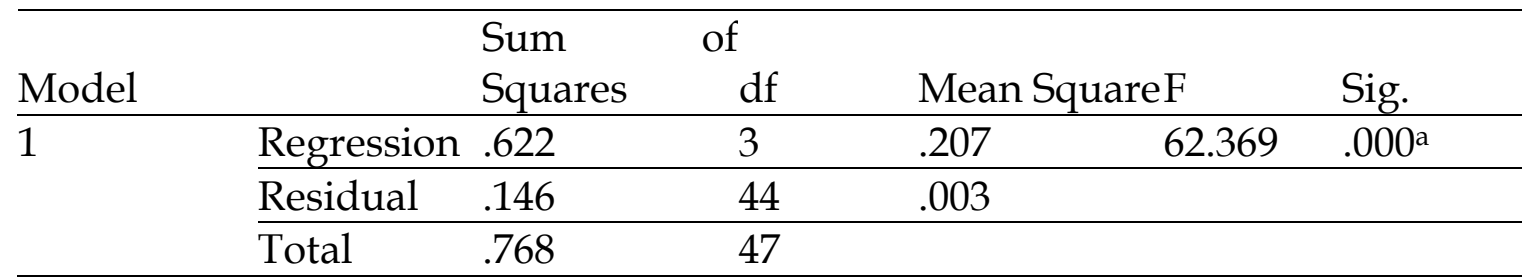

Sumber : data primer yang diolah

Berdasarkan hasil uji $\mathrm{F}$ di atas diperoleh $\mathrm{F}$ hitung sebesar 62,369 dan nilai signifikansi sebesar 0,000 yang lebih kecil dari nilai alfa sebesar 0,05. Dengan demikian diperoleh kesimpulan bahwa secara bersama-sama variabel pembiayaan murabahah, tingkat bagi hasil dan tingkat suku bunga acuan BI berpengaruh terhadap volume pembiayaan mudharabah perbankan syariah di Indonesia.

\section{Pembahasan}

\section{Pengaruh pembiayaan murabahah berpengaruh terhadap volume pembiayaan mudharabah}

Hasil uji hipotesis menunjukkan bahwa pembiayaan murabahah berpengaruh secara signifikan terhadap volume pembiayaan mudharabah dengan arah hubungan yang negatif. Artinya semakin besar jumlah pembiayaan murabahah di perbankan syariah akan menyebabkan volume pembiayaan mudharabah semakin kecil.

Hal ini merupakan konsekuensi logis dimana jika salah satu pembiayaan di perbankan syariah naik, maka berpotensi akan menyebabkan jenis pembiayaan lainnya turun. Dari hasil penelitian ini menunjukan bahwa pembiayaan murabahah merupakan salah satu faktor penting yang mempengaruhi volume pembiayaan mudharabah di perbankan syariah. Hal ini seharusnya menjadi perhatian serius bagi perbankan, pemerintah, ulama dan masyarakat mengingat pembiayaan murabahah bukanlah akad utama yang ada di perbankan syariah. Volume pembiayaan murabahah yang mengalami tren kenaikan setiap tahunnya sangat bertolak belakang dengan kondisi pembiayaan mudharabah yang menurun setiap tahunnya.

Untuk mempertahankan kelangsungan akad pembiayaan mudharabah diperlukan peran berbagai pihak baik itu perbankan, pemerintah, ulama maupun masyarakat. Indonesia sebagai Negara dengan jumlah penduduk muslim terbesar di dunia seharusnya mampu menjadi potensi tumbuh dan berkembangnya perbankan syariah melalui akad pembiayaan mudharabah dengan ciri khas bagi hasilnya. Dalam hal ini peran perbankan adalah berupaya untuk mengoptimalkan sumberdaya yang dimiliki dan memperbaiki manajemen yang ada. Pengenalan-pengenalan produk di bank syariah juga harus secara intensif dilakukan di semua lapisan masyarakat.

Pemerintah sebagai regulator juga mempunyai peran membuat kebijakankebijakan yang berpihak kepada perbankan syariah serta menciptakan rasa aman dan nyaman kepada masyarakat sehingga akan menyuburkan kepercayaan masyarakat kepada perbankan syariah. Peran ulama yang mempunyai akses secara langsung dengan masyarakat harus dimanfaatkan secara optimal untuk mensyiarkan dan 
mendakwahkan tentang keharaman riba serta keutamaan ekonomi syariah. Jika pemahaman masyarakat tentang haramnya riba ini dapat terlaksana dengan baik maka masyarakat akan berbondong-bondong meninggalkan bank konvensional dan beralih ke perbankan syariah.

Masyarakat juga perlu mengambil peran utama demi kesuksesan bank syariah. masyarakat Indonesia yang memiliki literasi yang rendah merupakan salah satu faktor yang menyebabkan pemahaman yang kurang dalam memaknai bank syariah. Mereka menganggap bahwa bank syariah sama saja dengan bank konvensional. Hal ini dapat dipahami karena pemahaman masyarakat yang rendah. Untuk itu, sebagai bagian dari masyarakat muslim, setiap masyarakat harus memiliki kesadaran untuk mencari informasi tentang keharaman riba dan melaksanakan transaksi berdasarkan akad syariah.

Jika keempat pihak ini dapat menjalankan perannya masing-masing dengan maksimal dan dapat bersinergi dengan baik, maka dapat dipastikan perkembangan perbankan syariah dapat tumbuh dengan pesat sehingga akad pembiayaan mudharabah yang menjadi identitas utama perbankan syariah dapat terjaga keberlangsungannya.

\section{Pengaruh tingkat bagi hasil terhadap volume pembiayaan mudharabah}

Hasil uji hipotesis menunjukkan bahwa tingkat bagi hasil berpengaruh secara signifikan terhadap volume pembiayaan mudharabah dengan arah hubungan yang positif. Artinya semakin besar tingkat bagi hasil di perbankan syariah akan menyebabkan volume pembiayaan mudharabah semakin besar.

Hal ini sejalan dengan penelitian yang dilakukan oleh Anisa dan Yaya (2015) yang melakukan penelitian tentang pengaruh tingkat bagi hasil terhadap volume dan porsi pembiayaan mudharabah. Hasilnya adalah bahwa tingkat bagi hasil berpengaruh secara positif dan signifikan terhadap pembiayaan bagi hasil.

Dalam menjalankan kegiatan operasionalnya, bank syariah sebagai entitas bisnis bersifat profit oriented yang bertujuan untuk mencari keuntungan. Keuntungan yang diharapkan merupakan salah satu cara bank dalam menetapkan jumlah pembiayaan yang akan disalurkan. Produk yang ditawarkan dari pembiayaan bagi hasil cenderung menghasilkan pendapatan dan keuntungan yang lebih besar dibandingkan jenis pembiayaan lainnya (Rahmat, 2012). Apabila bank syariah mampu mendapatkan pendapatan dan keuntungan yang besar, maka tingkat bagi hasil yang ditawarkan atau diberikan juga akan besar.

Hal ini merupakan salah satu faktor yang dapat meningkatkan jumlah pembiayaan syariah di perbankan syariah. Melihat kondisi persaingan yang ketat antar bank syariah mendorong setiap bank syariah untuk menawarkan tingkat bagi hasil terbaik atau bahkan terbesar dalam rangka menarik minat nasabah untuk mempercayakan dananya di bank syariah. Sebuah konsekuensi logis namun belum terlaksana dengan baik dalam prakteknya. Pada kenyataannya tingkat bagi hasil yang ditawarkan oleh perbankan syariah belum cukup menggiurkan di kalangan masyarakat sehingga menyebabkan volume pembiayaan mudharabah yang disalurkan menjadi rendah. 


\section{Pengaruh tingkat bagi hasil terhadap volume pembiayaan mudharabah}

Hasil uji hipotesis menunjukkan bahwa tingkat suku bunga acuan BI berpengaruh secara signifikan terhadap volume pembiayaan mudharabah dengan arah hubungan yang negatif. Artinya semakin besar tingkat suku bunga acuan BI akan menyebabkan volume pembiayaan mudharabah semakin kecil.

Hal ini sejalan dengan penelitian yang dilakukan oleh Widiyanto dan Diyani (2015) yang juga mendapatkan hasil bahwa tingkat suku bunga berpengaruh secara signifikan terhadap volume pembiayaan mudharabah. Kenaikan suku bunga BI rate secara langsung akan mempengaruhi perbankan syariah. Pengaruh secara langsung tersebut dapat berupa displaced commercial risk yaitu resiko berpindahnya dana dari perbankan syariah ke perbankan konvensional karena adanya perbedaan rate keuntungan yang kan diperoleh ketika terjadi perubahan tingkat suku bunga acuan BI.

Dana masyarakat yang berpindah dari perbankan syariah ke perbankan konvensional akan menyebabkan masalah likuiditas di perbankan syariah. Masyarakat akan lebih memilih menempatkan dananya di perbankan konvensional karena akan mendapatkan tingkat kembalian lebih besar dengan adanya bunga. Hal ini akan mempengaruhi kegiatan penghimpunan dana di perbankan syariah. Untuk mengantisipasi hal tersebut, salah satu langkah yang bisa ditempuh oleh bank syariah adalah dengan meningkatkan atau memberikan nisbah spesial bagi hasil pada waktu tertentu dimana tejadi kenaikan tingkat suku bunga acuan BI.

\section{SIMPULAN}

Berdasarkan hasil pembahasan hipotesis, maka kesimpulan dari penelitian ini adalah pertama, pembiayaan murabahah berpengaruh signifikan dengan arah hubungan yang negatif terhadap volume pembiayaan mudharabah perbankan syariah, dimana jika jumlah pembiayaan murabahah naik maka volume pembiayaan mudharabah akan turun. Kedua, tingkat bagi hasil berpengaruh signifikan dengan arah hubungan positif terhadap volume pembiayaan mudharabah perbankan syariah, dimana jika tingkat bagi hasil perbankan syariah naik, maka volume pembiayaan mudharabah juga akan naik. Ketiga, tingkat suku bungan acuan BI berpengaruh signifikan dengan arah hubungan negatif terhadap volume pembiayaan mudharabah perbankan syariah, dimana jika tingkat suku bunga acuan BI naik, maka volume pembiayaan mudharabah akan turun

\section{DAFTAR PUSTAKA}

Ali, Zainuddin. (2016). Hukum Perbankan Syariah. Jakarta: Sinar Grafika.

Andreany, Dita. (2011). Analisis Pengaruh DPK, Tingkat Bagi Hasil dan NPF terhadap Volume Pembiayaan Berbasis Bagi Hasil pada Perbankan Syariah di Indonesia. Simposium Nasional Akuntansi XIV Aceh.

Antonio, M. Syafi'i. (2001). Bank Syariah dari Teori ke Praktek. Jakarta: Gema Insani. 
Dahlan, Siamat. (2005). Manajemen Lembaga Keuangan Kebijakan Moneter dan Perbankan. Jakarta: Fakultas Ekonomi Universitas Indonesia.

Fatwa Dewan Syari'ah Nasional Majelis Ulama Indonesia No: 07/DSN-MUI/IV/2000 tentang Pembiayaan Mudharabah (Qiradh).

Furqaini, Nisa dan Yaya, Rizal. (2016).Faktor-faktor yang Mempengaruhi Volume dan Porsi Pembiayaan Berbasis Bagi Hasil pada Perbankan Syariah di Indonesia. JRAK: Jurnal Riset \& Komputerisasi Akuntansi, Vol. 7, No. 1 Februari 2016. http://jurnal.unismabekasi.ac.id/index.php/jrak/article/view/728/614

Ghozali, Imam. (2005). Analisis dengan Program SPSS. Semarang: Badan Penerbit Undip.

Gujarati N. Damodar. (2004). Basic Econometrics Fourth Edition. New York: McGrawHill.

Hair, J. F., Black, W. C., Babin, B. J., Anderson, R. E. (2006). Multivariate Data Analysis Pearson International Edition, Edition 6. New Jersey: Pearson Education.

Imama, Lely Shofa. (2014). Konsep dan Implementasi Murabahah pada Produk Pembiayaan Bank Syariah. Iqtishadia Jurnal Ekonomi dan Perbankan Syariah, Vol. 1 No. 2 (2014), h. 222-247.

Karim, Adiwarman. (2004). Bank Islam: Analisis Fiqih dan Keuangan. Jakarta: Raja Grafindo Persada.

Karim, Adiwarman. (2014). Bank Islam: Analisis Figh dan Keuangan. Jakarta: Raja Grafindo Persada.

Muhamad. (2005). Manajemen Bank Syariah. Yogyakarta: UPP AMP YKPN.

Muhamad. (2016). Manajemen Keuangan Syari'ah. Yogyakarta: UPP STIM YKPN.

Naufal, Tanesia G.N., Fadillah, Sri., Helliana. (2017). Pengaruh Dana Pihak Ketiga, Rasio Keuangan Bank, Inflasi dan BI Rate terhadap Volume Pembiayaan (Studi Pada Bank Umum Syariah yang Terdaftar di Bank Indonesia Periode 2012-2016). Prosiding Akuntansi, Vol. 3 No. 2 (2017).

Pratin dan Adnan, Akhyar. (2005). Analisis Hubungan Simpanan, Modal Sendiri, NPL, Prosentase Bagi Hasil dan Mark-Up Keuntungan Terhadap Pembiayaan Pada Perbankan Syariah Studi Kasus Pada Bank Muamalat Indonesia (BMI). Sinergi: Kajian Bisnis dan Manajemen Edisi Khusus on Finance, 2005, h. 35-52. https://journal.uii.ac.id/Sinergi/article/view/937/868 
Qomar, M. N. (2018). Mudharabah Sebagai Produk Pembiayaan Perbankan Syariah Perspektif Abdullah Saeed. Malia: Journal of Islamic Banking and Finance, Vol. 2 $\begin{array}{llll}\text { No. } 2018), & \text { h. }\end{array}$ http://journal.stainkudus.ac.id/index.php/syirkah/article/view/4890/3165

Rahmat, A. (2012). Optimalisasi Pembiayaan Bagi Hasil Sebagai Upaya Memberdayakan UMKM yang Berkeadilan. http:/ / syariah.cooperation.blogspot.com/2012/05/optimalisasi-pembiayaanbagi hasil.html (Diakses tanggal 3 September 2019).

Rose, Peter S. dan James W. Kolari. (1995). Financial Institution: Understanding and managing financial services. USA: Richard D. Irwin, Inc.

Ruslizar, Rahmawaty. (2016). Pengaruh Tingkat Bagi Hasil Deposito Mudharabah, Financing to Deposit Ratio, dan Suku Bunga Deposito Terhadap Pertumbuhan Deposito Mudharabah Pada Bank Umum Syariah di Indonesia. Jurnal Ilmiah Mahasiswa Ekonomi Akuntansi (JIMEKA), Vol. 1 No. 2 (2016), h. 84-90.

Sa'diyah, Mahmudatus, dan Arifin, M. A. (2013). Mudharabah dalam Fiqh dan Perbankan Syariah. Equilibrium, Vol. 1 No. 2 Desember 2013, h. 302-303.

UU No 10 Tahun 1998 tentang Perubahan Atas Undang-undang No. 7 Tahun 1992 tentang Perbankan.

Widiyanto dan Diyani. (2015). Analisis Pengaruh Tingkat Suku Bunga BI Terhadap Pembiayaan Mudharabah. Kalbisocio Volume 2 No. 1 Februari 2015.

Wiroso. (2011). Akuntansi Transaksi Syariah. Jakarta: Ikatan Akuntan Indonesia.

Yaya, R., Martawireja, Erlangga, dan Abdurrahim, Ahim. (2009). Akuntansi Perbankan Syariah Teori dan Praktek Kontemporer. Jakarta: Penerbit Salemba. 
Emy Widyastuti

Halaman ini sengaja dikosongkan 